DOI:10.22337/2587-9618-2019-15-4-111-122

\title{
MODELING OF BLAST EFFECTS ON UNDERGROUND STRUCTURE
}

\author{
Oleg V. Mkrtychev, Anton Y. Savenkov \\ National Research Moscow State University of Civil Engineering, Moscow, RUSSIA
}

\begin{abstract}
Modeling of the impact of a point explosion shock wave on a soil mass and an underground structure at different locations of the explosion epicenter from the ground surface was performed. The study of the stressstrain state of soils was carried out using a nonlinear dynamic method and a fully coupled numerical model, including various models of materials. The result of numerical modeling showed the adequacy of the adopted numerical calculation methods. The findings showed that solving the problem in a nonlinear dynamic formulation allows obtaining the parameters of the shock wave at different depths from the explosion center, as well as obtaining a complete picture of the interaction of the shock wave with the underground structure in surface and underground explosions.
\end{abstract}

Keywords: explosion loads, shock wave, compression wave, nonlinear dynamics, stress-strain state, underground structure, soil model

\section{МОДЕЛИРОВАНИЕ ВОЗДЕЙСТВИЯ УДАРНОЙ ВОЛНЫ НА ПОДЗЕМНОЕ СООРУЖЕНИЕ}

\author{
О.В. Мкртычев, А.Ю. Савенков \\ Национальный исследовательский Московский государственный строительный университет, \\ г. Москва, РОССИЯ
}

\begin{abstract}
Аннотация: Выполнено моделирование воздействия ударной волны точечного взрыва на грунтовый массив и подземное сооружение при различном расположении эпицентра взрыва от поверхности грунта. Исследование напряженно-деформированного состояния грунтов осуществлялось с использованием нелинейного динамического метода и полностью связанной численной модели, включающей различные модели материалов. Результат численного моделирования показал адекватность принятых численных методик расчета. Сделанные выводы показали, что решение задачи в нелинейной динамической постановке позволяет получить параметры ударной волны на различных глубинах от центра взрыва, а также получить полную картину взаимодействия ударной волны с подземным сооружением при поверхностном и подземном взрыве.
\end{abstract}

Ключевые слова: взрывные воздействия, ударная волна, волна сжатия, нелинейная динамика, напряженно-деформированное состояние, подземное сооружение, грунтовая модель

\section{INTRODUCTION}

Currently, various industrial undertakings are being built, relating to oil and gas and space industries, as well to nuclear power facilities, which include underground structures. Such underground structures include repositories, shelters, civil defense shelters, command posts, etc.

The current design standards [1-4] require the calculation of such structures for emergency ac- tions, including explosions. At the same time, the structures located on the surface have been thoroughly studied and there are a sufficient number of approved calculation methods for them, including the explosion triggered progressive collapse, earthquake loads, and fires [5-8]. For example, the most common methods are equivalent-static, linear-spectral, as well as direct dynamic methods of calculation [9-11], while there are not enough methods for under- 
ground structures and they are in great demand, in which case the problem is complicated, since it is necessary to take into account the soil surrounding the underground structure. Therefore, there is a need to find and study new approaches to solving the problem of the interaction of shock waves with a structure.

\subsection{Work relevance.}

The relevance of the work lies in solving the problem of the interaction of a point explosion shock wave with an underground structure using a nonlinear dynamic method of calculation and a fully coupled numerical model, including the model of the soil, air, and an underground structure.

\subsection{Study objective.}

The primary objective of this study is to investigate the soil strain-stress state and the response of an underground structure soil under various explosion scenarios. To achieve this goal, the specific objectives of the study include:

- analysis of soil behavior under explosive loads;

- analysis of soil models used in the calculation of underground structures for explosive loads;

- a study of the strain-stress state of the soil mass in the propagation of shock and seismic waves; and

- modeling of loads on an underground structure.

\section{MATERIALS AND METHODS}

\subsection{Soil model.}

Soils tend to have a complex structure consisting mainly of mineral particles that form the soil skeleton. The space between the solid particles is filled with air and/or water. When the pores between the solid particles are filled with air, the soil is of the dry type. When the pores are filled with water containing a small proportion of air, the soil is called saturated soil. Therefore, in general, soils can be called three-phase soils
(Figure 1). Relative volume fractions of the three constituent materials of the soil are usually quantitatively determined by the porosity $\alpha$ and the saturation degree $\beta$.

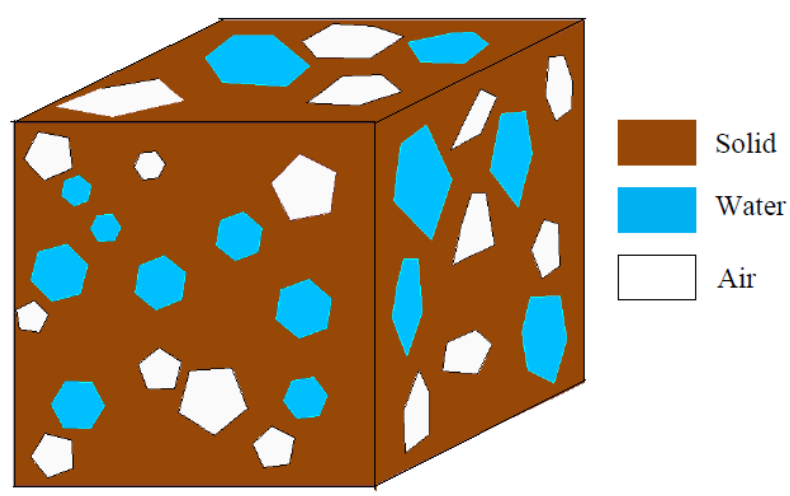

Figure 1. Soil element.

- For many processes with a low loading rate (under static loads), the overall macroscopic behavior of the soil skeleton can be determined within the framework of the principles of continuum mechanics, which makes it possible to simplify modeling and apply theories and methods of continuum mechanics. Under conditions of fast loading, which are typical for explosions, soil models should include constitutive models of three phases necessary for determining the soil behavior; thus, different soil behavior should be taken into account, namely:

- Dilatancy/contraction: Shear strains in soils can lead to volume changes. This determines the relationship between the shear strength of the soil and its strain properties. This effect was first described by Osborne Reynolds in 1885-1886 and was called dilatancy and the decrease in volume is called negative dilatancy or contraction. In dense sand and overcompacted clay, with a displacement, the height of the sample is increased by a certain amount, thereby increasing the soil volume, and in loose sand and normally compacted clay, a decrease in volume can be observed. Thus, the shear stress initially rises rapidly to a peak value with a relatively low displacement value with a corresponding increase in 
volume. With this new volume, the blocking is reduced, and, therefore, as the displacement continues, the shear stress decreases and, finally, is aligned with the final residual value.

- Such a nature of strain is explained by the fact that when one part of the soil is displaced relative to another, its shear strength is determined by sliding friction. To overcome the adhesion forces, it is necessary to extend and uplift them to a certain level, in which case loosening occurs in the shear zone, which is accompanied by a decrease in its shear strength. Thus, dense soils become looser, as a result of dilatancy, and loose soils become denser, as a result of contraction.

- Plasticity: An increase in the applied stress usually results in some irreversible strain, with no signs of cracking or failure. Most soils have a very small elastic area and show plasticity from the beginning of loading.

- Hardening/softening (thixotropy): It is the ability of soils to reduce their viscosity (to liquefy), as a result of mechanical damage, and increase the viscosity at rest. Freundlich found that thixotropy is manifested in soils, in which the content of clay particles exceeds $2 \%$. It is suggested that all clay soils are potentially thixotropic, but for a specific manifestation of thixotropy, certain conditions and, first of all, quite intense exposures are necessary (Figure 2).

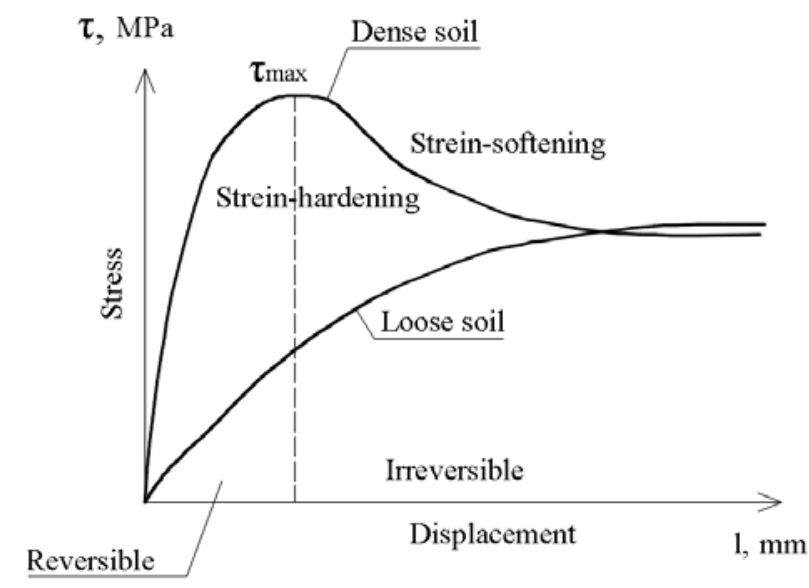

Figure 2. Response of soil with respect to shearing.
- High strain rate behavior: Soils with different water content exhibit different behavior at high strain rates. In experiments with different soils from sands to clays, it was noted that with a decrease in the loading time (an increase in the loading rate), the compressive strength increases. Thus, in clay soils, when comparing experiments with a loading rate of $0.02 \mathrm{~s}$ with tests at a loading rate of $10 \mathrm{~min}$, the strength increased by $1.5-2$ times and smaller values were obtained for more durable clays. In sandy soils, the effect of loading rate was significantly lower and the strength increment did not exceed $15 \%$ of the static value.

With repeated impulses and vibrations, all observations and experiments show the opposite picture, a significant reduction in the soil shear resistance in some cases.

- Effects of drainage and volume changes: In saturated soils, an increase in the applied compressive stress causes an increase in the pore pressure of water. If drainage is possible, water outflows to the surrounding areas, where the water pore pressure is lower. The outflow rate depends on the soil permeability; in gravel and sand, it is relatively fast and in silts and clays, it is slow. When the excess pressure of the pore water is dissipated, the applied stress is transferred from the pore pressure to the effective stress.

It should be noted that there are also other characteristics of soil behavior, such as creep and temperature dependence. These aspects are not discussed here, since they are beyond the scope of this study.

The mechanical behavior of soils can be modeled at many levels. Hooke's law of linear isotropic elasticity can be considered as the simplest of the available stress-strain relations, but, as a rule, it is too rough to grasp the main characteristics of the soil behavior. On the other hand, several researchers have proposed a large number of soil models to describe the soil behavior in various aspects in detail. However, the number of soil models that are suitable for implementation in 
advanced software systems using finite element methods is rather limited.

Let us consider the most commonly used soil models that can predict the soil behavior described above. These models include elastic, perfectly plastic soil models, hardeningplastic soil models, elastic-viscous soil models, three-phase soil models, viscoplastic soil models, SFG unsaturated soil model, and unsaturated plasticity models of the bounding surface.

The most commonly used soil models that can predict the soil behavior described above are:

Elastoplastic soil models:

- Mohr-Coulomb model;

- Drucker-Prager model.

- Hardening soil models;

- Cam-clay tent model (for some soils it is required that they were tent-like, so that there would be a limitation on the resulting hydrostatic pressure);

- Three-phase soil models;

- Viscoplastic soil models.

Among them, the most commonly used in practice is the Mohr-Coulomb model. In further work we will accept it as the main one.

A classical Mohr-Coulomb model is described by the following strength conditions, which have a different appearance under different test conditions. The first strength condition:

$$
\tau=\sigma_{v} \operatorname{tg} \varphi^{\prime}+c^{\prime}
$$

- consolidated-drained shear;

$$
\tau=\left(\sigma_{v}-u\right) \operatorname{tg} \varphi+c
$$

- consolidated-undrained shear;

$$
\tau=c_{u}
$$

- unconsolidated-undrained shear (for watersaturated soils);

$$
\tau=\left(u_{a}-u\right) \operatorname{tg} \varphi^{b}+\left(\sigma_{v}-u\right) \operatorname{tg} \varphi^{\prime}+c^{\prime}
$$

$$
\tau=\sigma_{v} \operatorname{tg} \varphi_{r}^{\prime}+c_{r}^{\prime}
$$

- in the case of large shear strains.

where $\tau$ is a shear stress, upon reaching which the destruction of the ground will occur; $\sigma_{v}-$ is an effective normal stress; $\varphi^{\prime}-$ is an effective angle of internal friction; $\varphi-$ is a drained angle of internal friction; $c$ - are drained specific adhesion forces; $c$ ' - is effective specific adhesion forces; $u_{\mathrm{a}}-$ is a pore air pressure; $u-$ is a pore water pressure; $\varphi_{b}$ is an angle of internal friction, depending on the magnitude of the matrix suction; $\varphi_{r}^{\prime}-$ is a residual angle of internal friction; $c_{r}^{\prime}-$ are residual specific adhesion forces; and $c_{u}-$ is an undrained strength.

Second strength condition:

$$
\sin \varphi=\frac{\sigma_{1}-\sigma_{3}}{\sigma_{1}+\sigma_{3}}
$$

- for gravel, sandy and coarse soils;

$$
\frac{\sigma_{1}-\sigma_{3}}{\left(\sigma_{1}+\sigma_{3}+2 \operatorname{cctg} \varphi\right)}=\sin \varphi
$$

- for clay soils.

With a three-dimensional stress-strain state, the equation takes the following form:

$$
\left.\begin{array}{l}
\left|\sigma_{1}-\sigma_{2}\right|=\left(2 \operatorname{cctg} \varphi-\sigma_{1}-\sigma_{2}\right) \sin \varphi \\
\left|\sigma_{2}-\sigma_{3}\right|=\left(2 \operatorname{cctg} \varphi-\sigma_{2}-\sigma_{3}\right) \sin \varphi \\
\left|\sigma_{3}-\sigma_{1}\right|=\left(2 \operatorname{cctg} \varphi-\sigma_{3}-\sigma_{1}\right) \sin \varphi
\end{array}\right\}
$$

According to this equation, the Mohr-Coulomb yield surface in the space of primary stresses has the form of a hexagonal pyramid (Figure 3), with a vertex at the point with coordinates. $\{\operatorname{cctg} \varphi ; \operatorname{cctg} \varphi ; \operatorname{cctg} \varphi\}$

As is obvious, this model describes different types of soil, with different water saturation. But in addition to the classical model, there are other modifications of the model used for certain specific tasks.

- consolidated-untrained shear, sedentary soils; 


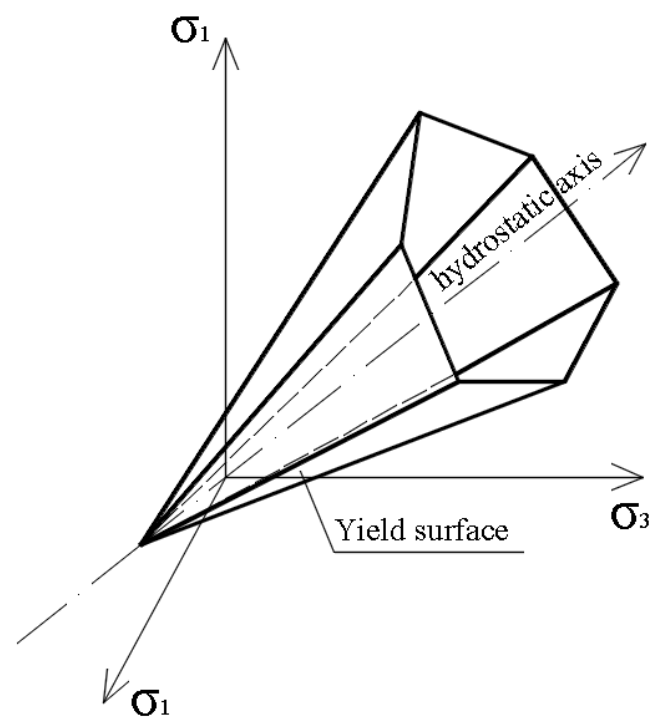

Figure 3. Mohr-Coulomb yield surface in the space of primary stresses.

For example, the Mohr-Coulomb model based on the works of A.J. Abbo and S.W. Sloan performed in 1995 [12,13], taking into account all the above-mentioned soil behaviors, as well as the removal of elements, which is typical for explosive loads $[14,15]$. Therefore, we will use this version of the Mohr-Coulomb model.

The usual Mohr-Coulomb yield surface is described by the function:

$$
F=-P \sin \varphi+K(\theta) \sqrt{J_{2}}-c \cos \varphi=0
$$

where $P$ is a mean pressure; $\varphi$ is an angle of internal friction; $K(\theta)$ is a function of the angle $\theta$ in the deviator plane; $\sqrt{J_{2}}$ is a square root of the second invariant of the stress deviator; and $C$ is an adhesion.

The modified yield surface is a hyperboloid "fitted" to the Mohr-Coulomb surface. The modified surface equation has the following form:

$$
\begin{gathered}
F=-P \sin \varphi+\sqrt{J_{2} K(\theta)^{2}+a^{2} \sin ^{2} \varphi} \\
-c \cos \varphi=0
\end{gathered}
$$

where " $a$ " is a parameter that determines the approximation of the modified surface to the ordinary Mohr-Coulomb surface.

\subsection{Air model.}

The model used in the calculation is described by a polynomial equation:

$$
\begin{gathered}
p=C_{0}+C_{1} \mu+C_{2} \mu^{2}+C_{3} \mu^{3}+\left(C_{4}+C_{6}\right. \\
\left.+C_{7} \mu^{2}\right) E \\
\mu=\frac{1}{V}-1
\end{gathered}
$$

where $V$ - relative volume, $E$ - internal energy.

\subsection{Model of an explosive.}

The explosive model is described by the JonesWilkins-Lee (JWL) equation of state:

$$
\begin{aligned}
& p=A\left(1-\frac{\omega}{R_{1} V}\right) e^{-R_{1} V}+B\left(1-\frac{\omega}{R_{2} V}\right) \\
& e^{-R_{2} V}+\frac{\omega E}{V}
\end{aligned}
$$

\subsection{Modeling methods.}

Since the explosion in the ground has a highly linear character, for this purpose the best option is to apply a numerical calculation method using arbitrary ALE Lagrangian-Eulerian meshes, where Eulerian meshes were used for air, soil, and explosive and Lagrangian meshes were used for an underground structure.

To solve the problem, we will use the LSDYNA software suite, which allows solving such problems in a nonlinear dynamic formulation, using the central difference method [1618].

For approximation of the equations in this work, the second-order Godunov method was used. The time integration of the equations was carried out using an explicit second order accuracy scheme (central difference method) with the observance of the scheme stability condition according to the Courant criterion.

A differential equation of motion of a system with a finite number of degrees of freedom:

$$
M \ddot{u}+C \dot{u}+K u=f^{a}
$$

for an explicit scheme, it looks like this:

$$
M \ddot{\tilde{u}}_{t}+C \dot{u}_{t}+K u_{t}=f_{t}^{a}
$$



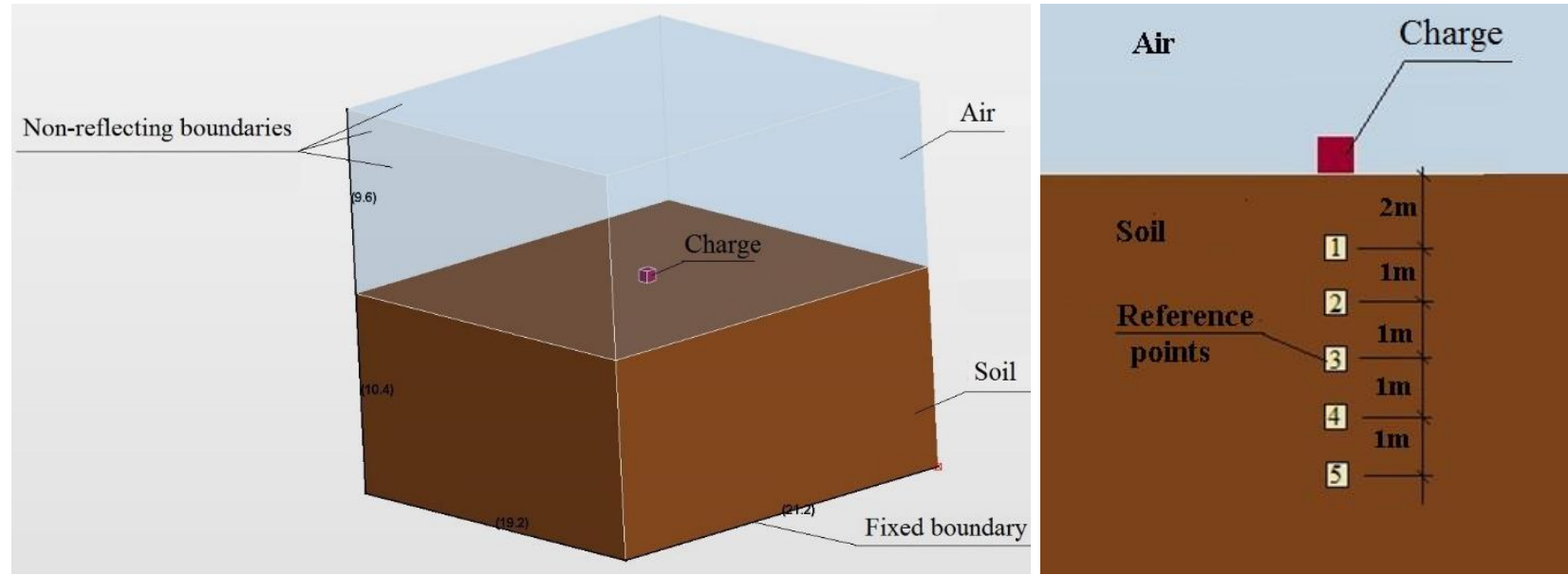

Figure 4. Computational model and layout of reference points.
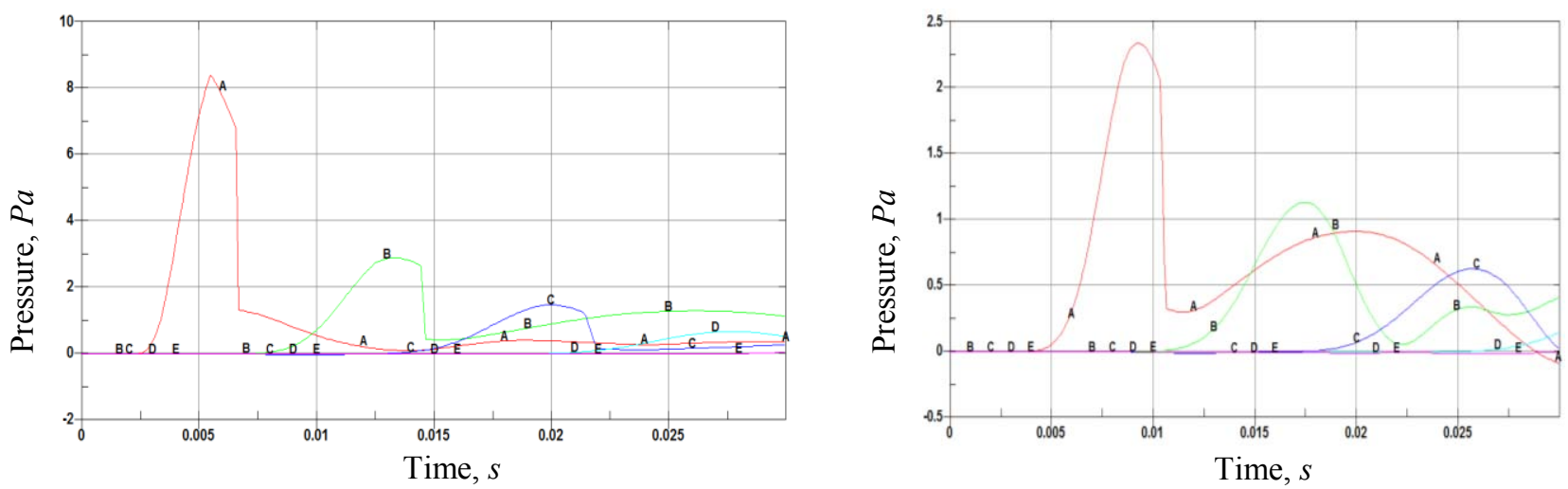

a)

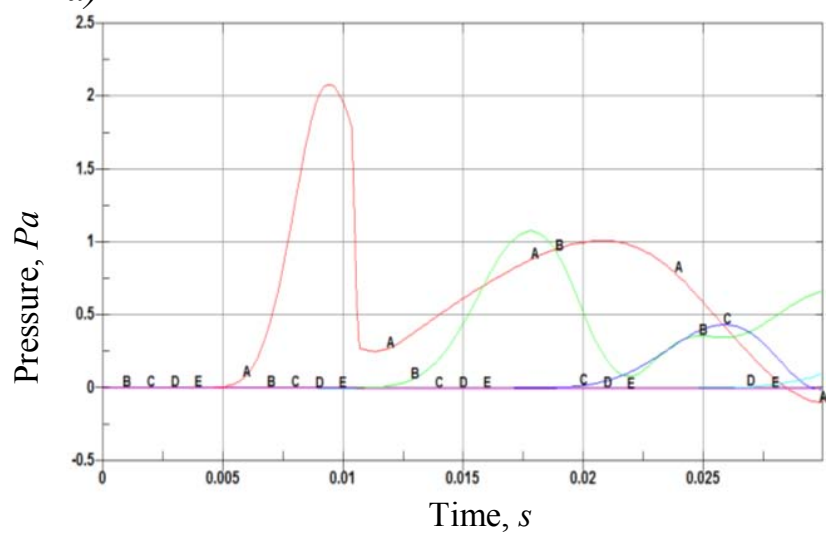

c)

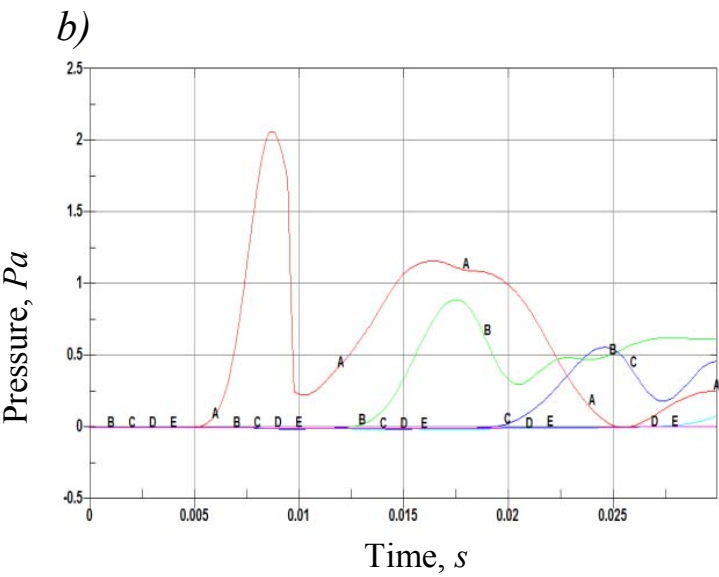

d)

Figure 5. Results of the finite element mesh convergence study with dimensions: a) 0,3 $m$; $b$ ) $0,25 \mathrm{~m} ; \mathrm{c}$ ) $0,2 \mathrm{~m}$; d) $0,15 \mathrm{~m}$ (where A,B,C,D,E-numbers of reference points).

Acceleration vector:

$$
a_{t}=M^{-1}\left(f_{t}^{e x t}-f_{t}^{i n t}\right)
$$

where $f_{t}^{\text {ext }}$ - external force vector; $f_{t}^{\text {int }}-$ internal force vector.
Accounting for various types of non-linearities is performed through the internal force vector $\{\mathrm{F}\}$ :

$$
f_{t}^{\text {int }}=\sum\left(\int_{\Omega}\left[B^{T}\right]\{\sigma\} d \Omega+\left\{F^{\text {cont }}\right\}\right)
$$


where B - deformation-displacement matrix; $\sigma$ displacement vector; $F^{\text {cont }}$ - contact force vector. The velocity and displacement vectors in the corresponding step are determined as follows:

$$
\begin{gathered}
v_{t+\Delta t / 2}=v_{t-\Delta t / 2}+a_{t} \Delta t \\
u_{t+\Delta t}=u_{t}+v_{t+\Delta t / 2} \frac{\Delta t_{t}+\Delta t_{t+\Delta t}}{2}
\end{gathered}
$$

\section{STUDY RESULTS}

For the analysis of soil strain-stress state, a computational model was created with dimensions of $20.0 \times 20.0 \times 20 \mathrm{~m}(\mathrm{~h})$ (Figure 4). In this model, the ground and air areas, as well as an explosive weighing $200 \mathrm{~kg}$ were modeled using solid elements.

When using the central difference method, the accuracy of the calculations largely depends on the size of the region to be broken, in other words, in our case, on the size of the solid finite elements. Several computational models with variable size of solid finite elements from $0.3 \mathrm{~m}$ to $0.15 \mathrm{~m}$ were considered.

The optimal model was chosen with a cell size of $0.2 \mathrm{~m}$, in which the difference with the reference diagram of $0.15 \mathrm{~m}$ did not exceed $5 \%$. The structure is located at a depth of $3 \mathrm{~m}$ (Figure 5). a)

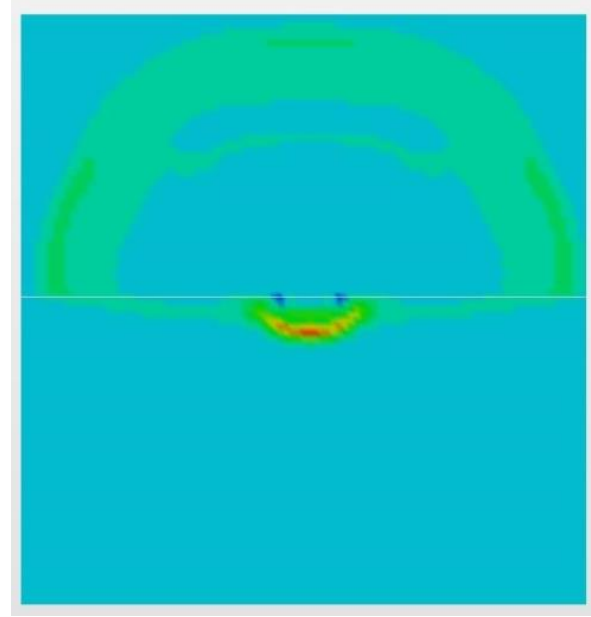

c)

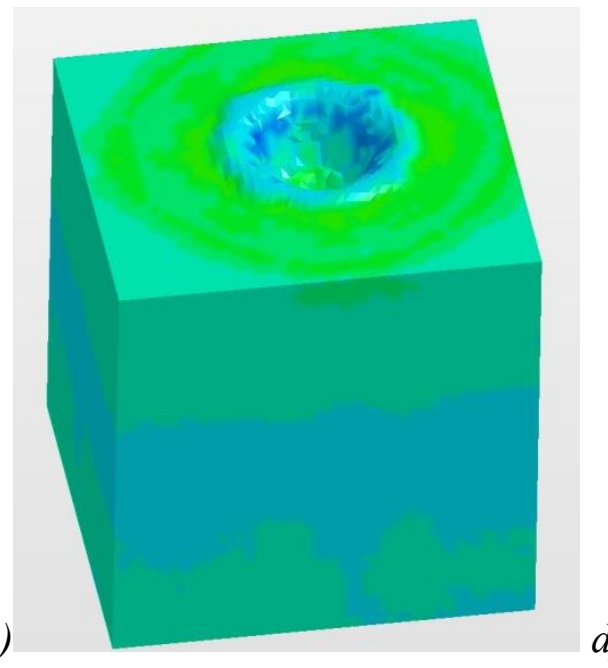

Figure 6. Isopoles of pressures at time points: a) 0,0077 s; b) 0,022 s; c) formation of explosive crater; d) propagation of air shock waves and compression wave.

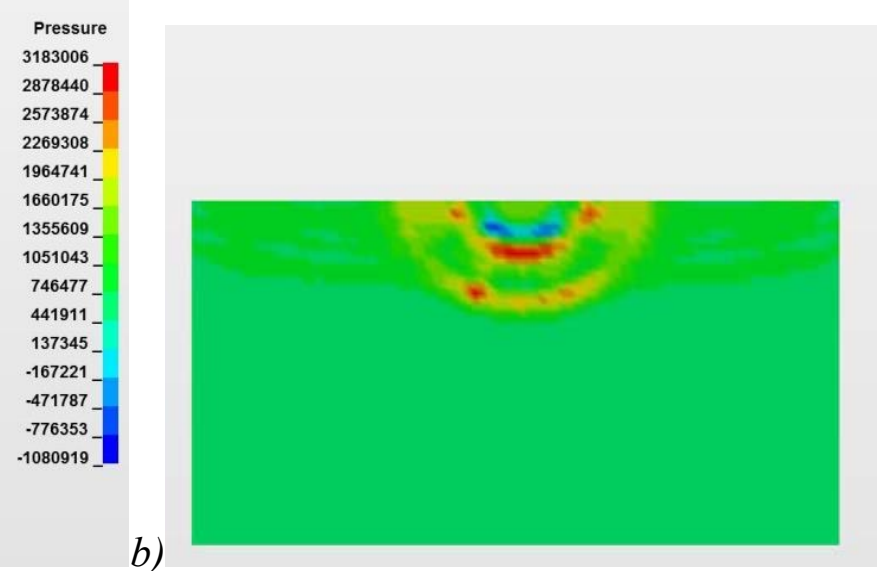

Pressure 843989 747029 650069 553109 456149 . 359190 262230 165270

68310 -28650 . $-125610$ 222570 $-319530$ $-416490$ $-513450$

$-1655007$ 
a)
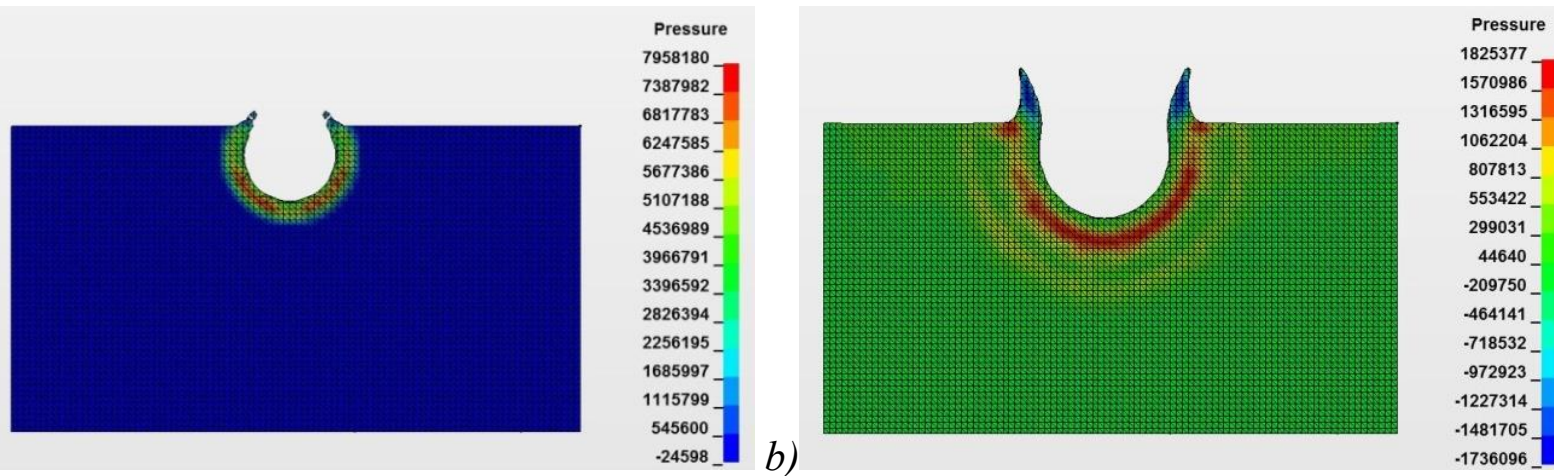

c)
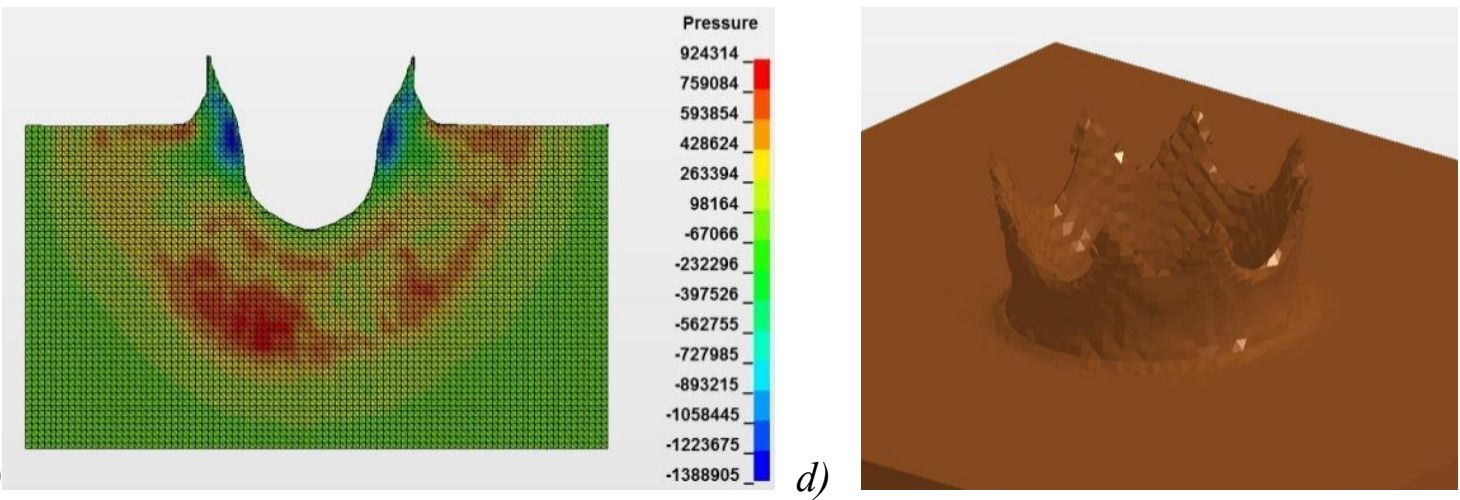

Figure 7. Isopoles of pressures at time points: a) 0,0077 s; b) 0,026 s; c) 0,056 s; d) formation of explosive crater.

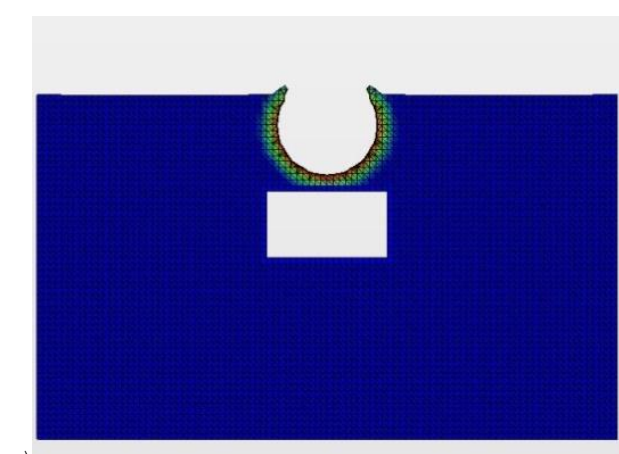

a)
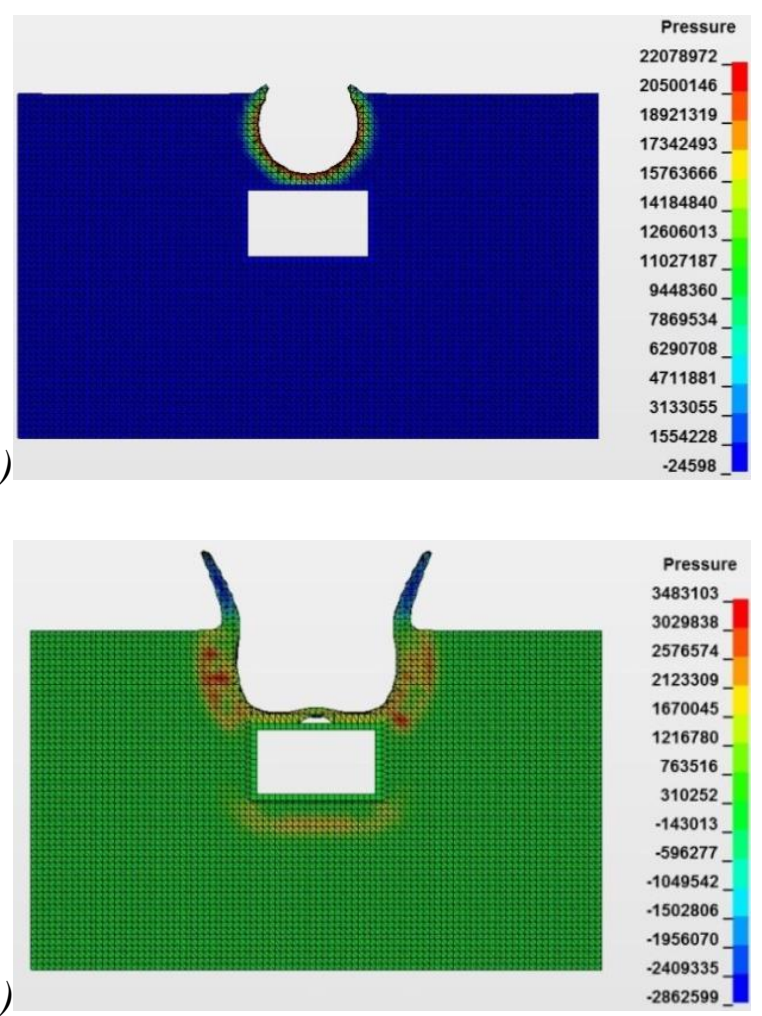

b)
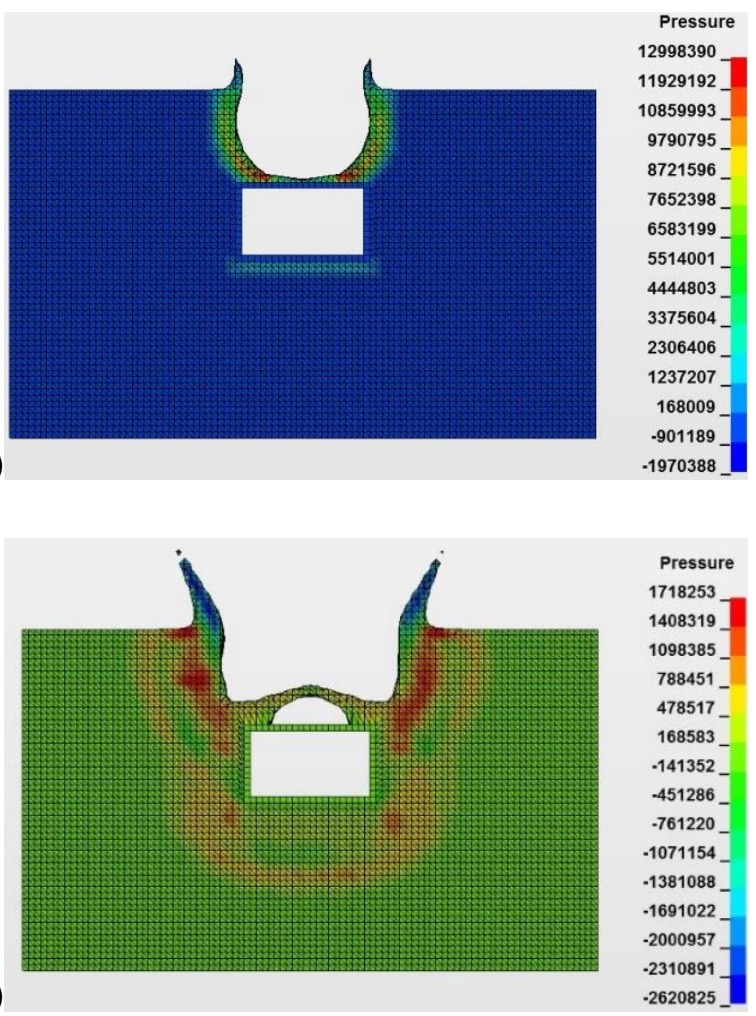

Figure 8. Isopoles of pressures at time points: a) $0,0077 \mathrm{~s} ;$ b) $0,01 \mathrm{~s}$; c) $0,022 \mathrm{~s} ;$ d) $0,05 \mathrm{~s}$. 


\subsection{Explosion on the ground surface.}

The propagation of a shock wave during an explosion on the ground surface is considered (Figure 6), where it can be seen that immediately after detonation, spherical shock waves propagated in the air from the charge epicenter, which was on the ground surface. Shock waves penetrated the ground in the form of hemispherical waves, forming a crater in the ground, followed by the propagation of seismic waves.

\subsection{The explosion at a depth of $1 \mathrm{~m}$.}

Next, an explosion at a depth of $1 \mathrm{~m}$ from the ground surface was considered (Figure 7).

Taking into account the results of these two loading cases, it can be concluded that the most dangerous case is an explosion at a depth of 1 $\mathrm{m}$, since the propagating seismic waves have a greater depth and blast pressure.

\subsection{Impact of an explosion on an under- ground structure at a depth of $1 \mathbf{~ m}$.}

Figure 8 shows the impact of an explosion on an underground structure at a depth of $1 \mathrm{~m}$. The wave front reached the surface of the structure within $7 \mathrm{~ms}$ from the beginning of the explosion. The blast pressure was $1.7 \mathrm{MPa}$.

\section{CONCLUSIONS}

The parameters of the shock wave in an explosion on the surface and at a depth of $1 \mathrm{~m}$ were compared with empirical values using the formulas [19] and the calculation results with accuracy of $5-10 \%$ coincide, which proves the adequacy of the adopted numerical calculation methods. Solving the problem in a nonlinear dynamic formulation makes it possible to obtain the parameters of a shock wave at different depths from the explosion center, as well as to get a complete picture of the shock wave interaction with the underground structure during a surface and underground explosion.

\section{REFERENCES}

1. Federal'nyy zakon No. 68 ot 11.11 .1994 "O zashchite naseleniya i territoriy ot chrezvychaynykh situatsiy prirodnogo i tekhnogennogo kharaktera" (in Russian).

2. Design Code of the Russian Federation SP 248.1325800.2016. Svod Pravil. Sooruzheniya podzemnyye. [Underground structures. Design principles] (In Russian).

3. Design Code of the Russian Federation SP 88.13330.2014. Svod Pravil. Zashhitnye sooruzheniya grazhdanskoj oborony. Aktualizirovannaya redaktsiya SNiP II-11-77* [The protective shelters of civil defense. Updated Version of SNiP II-11-77*] (in Russian).

4. Design Code of the Russian Federation SP 56.13330.2011. Svod Pravil. Proizvodstvennyye zdaniya. Aktualizirovannaya redaktsiya SNiP 31-03-2001 [Production buildings. Updated Version of SNiP 31-032001] (in Russian).

5. Mkrtychev O.V., Dorozhinskiy V.B. (2012). Analiz podkhodov k opredeleniyu parametrov vzryvnogo vozdeystviya [Analysis of approaches to determining the parameters of explosive exposure]. // Vestnik $M G S U$, 2012, No. 5, pp. 45-49 (in Russian).

6. Mkrtychev O.V., Dorozhinskiy V.B., Lazarev O.V. (2011). Raschet konstruktsiy zhelezobetonnogo zdaniya na vzryvnyye nagruzki v nelineynoy dinamicheskoy postanovke [Structural analysis of reinforced concrete buildings for explosive loads in a nonlinear dynamic formulation]. // Vestnik $M G S U, 2011$, No. 4, pp. 243-247 (in Russian).

7. Mkrtychev O.V., Dorozhinskiy V.B., Sidorov D.S. Nadezhnost' stroitel'nykh konstruktsiy pri vzryvakh i pozharakh [Reliability of building structures during explosions and fires]. Moscow, ASV Publishing House, 2016, 173 pages (in Russian).

8. Mkrtychev O.V., Savenkov A.Y. Chislennoye modelirovaniye fronta vozdushnoy 
udarnoy volny pri vzryve $\mathrm{v}$ vozdukhe i nad zemley $\mathrm{v}$ programmnom komplekse LSDYNA [Numerical simulation of the front of an air shock wave in a ground and air explosion in the software package LSDYNA]. // Structural mechanics of engineering constructions and buildings, 2018, No. 14(6), pp. 467-474 (in Russian).

9. Savenkov A.Y., Mkrtychev O.V. Nelineynyy raschet zhelezobetonnogo sooruzheniya na vozdeystviye vozdushnoy udarnoy volny [Nonlinear calculation of reinforced concrete structure to the impact of the air shock wave]. // Vestnik MGSU, 2019, No. 14(1), pp. 33-45 (in Russian).

10. Rastorguev B.S., Plotnikov A.I., Khusnutdinov D.Z. Proektirovanie zdaniy i sooruzheniy pri avariynykh vzryvnykh vozdeystviyakh [Design of Buildings and Structures Exposed to Emergency Blast Effects]. Moscow, ASV Publishing House, 2007, 152 pages (in Russian).

11. Pavlov A.S. Chislennoye modelirovaniye vzryvnykh vozdeystviy na zdaniya i soorugeniya proizvol'noy formy. [Numerical method of calculation of blast loads pressure to structures with complex geometry Shapes]. // Academia. Architecture and construction, 2017, No. 3, pp. 108-112 (in Russian).

12. Boldyrev G.G., Aref'yev D.V., Muyzemnik A.Yu. Identifikaciya parametrov modeley gruntov [Identification of soil model parameters]. URL: https://docplayer.ru/68796939-

Identifikaciya-parametrov-modeley-

gruntov-boldyrev-g-g-arefev-d-v-

muyzemnik-a-yu-ooo-npp-geotek-

annotaciya.html

13. Manual for LS-DYNA Soil Material Model 147 Evaluation / Report No FHWA-HRT-04095. Lincoln, University of Nebraska, 77 pages.

14. Huang Y., Willford M.R. Validation of LS-DYNA ${ }^{\circledR}$ MMALE with Blast Experiments // 12th International LS-DYNA ${ }^{\circledR}$ Users Conference. 2012. URL: https://www.dynalook.com/12thinternational-ls-dyna-conference/blastimpact20-c.pdf

15. Goel M., Matsagar V., Gupta A. An Abridged Review of Blast Wave Parameters. // Defense Science Journal, 2012, Volume 62, Issue 5, pp. 300-306.

16. Bate K., Wilson E. Chislennyye metody analiza i metod konechnykh elementov [Numerical analysis methods and the finite element method]. Moscow, Stroyizdat, 1982, 448 pages (in Russian).

17. Van Leer B.J. Towards the ultimate conservative difference scheme. Second-order sequel to Godunov's Method. // Journal of Computational Physics, 1979, Volume 32, Issue 1, pp. 101-136.

18. LS-DYNA. Keyword user's manual. 2017. Volume I. Version 971. Livermore Software Technology Corporation (LSTC). URL:

https://www.dynasupport.com/manuals/lsdyna-manuals/ls-dyna-manual-r-8.0-vol-iii

19. Orlenko L.P., Andreev S.G., Babkin A.V., Baum F.A., Imhovik N.A., Kobylkin I.F., Kolpakov V.I., Ladov S.V., Odintsov V.A., Ohitin V.N., Selivanov V.V., Soloviev V.S., Stanyukovich K.P., Chelyshev V.P., Shehter B.I. Fizika vzryva [Physics of a Blast]. Volume 2. Moscow, Fizmatlit Publ., 2004, 832 pages (in Russian).

\section{СПИСОК ЛИТЕРАТУРЫ}

1. Федеральный закон №68 от 11 ноября 1994 г. «О защите населения и территорий от чрезвычайных ситуаций природного и техногенного характера».

2. СП 248.1325800.2016. Свод правил. Сооружения подземные. Правила проектирования. Утв. Приказом Минрегиона России от 16.06.2016. №416/пр.

3. СП 88.13330.2014. Свод правил. Защитные сооружения гражданской обороны. Актуализированная редакция СНиП II- 
11-77*. Утв. Приказом Минрегиона России от 18.02.2014. №59/пр.

4. СП 56.13330.2011 Свод правил. Производственные здания. Актуализированная редакция СНиП 31-03-2001. Утв. Приказом Минрегиона России от 30.12.2010. №850.

5. Мкртычев О.В., Дорожинский В.Б. Анализ подходов к определению параметров взрывного воздействия. // $\mathrm{Becm}$ ник МГСУ, 2012, №5, с. 45-49.

6. Мкртычев О.В., Дорожинский В.Б., Лазарев О.В. Расчет конструкций железобетонного здания на взрывные нагрузки в нелинейной динамической постановке. // Вестник МГСУ, 2011, №4, с. 243-247.

7. Мкртычев О.В., Дорожинский В.Б., Сидоров Д.С. Надежность строительных конструкций при взрывах и пожарах. M.: ACB, 2016. - 173 c.

8. Мкртычев О.В., Савенков А.Ю. Численное моделирование фронта воздушной ударной волны при взрыве в воздухе и над землей в программном комплексе LS-DYNA. // Строительная механика инженерных конструкичии и сооружений, 2018, Том 14, №6, с. 467-474.

9. Савенков А.Ю., Мкртычев О.В. Нелинейный расчет железобетонного сооружения на воздействие воздушной ударной волны. // Вестник МГСУ, 2019, Том 14, Выпуск 1, с. 33-45.

10. Расторгуев Б.С., Плотников А.И., Хуснутдинов Д.3. Проектирование зданий и сооружений при аварийных взрывных воздействиях. - М.: АСВ, 2007. - 152 с.

11. Павлов А.С. Численное моделирование взрывных воздействий на здания и сооружения произвольной формы // Academia. Aрхитектура и строительство, 2017, №3, с. 108-112.

12. Болдырев Г.Г., Арефьев Д.В., Муйземник А.Ю., Идентификация параметров моделей грунтов. URL: https://docplayer.ru/68796939Identifikaciya-parametrov-modeley- gruntov-boldyrev-g-g-arefev-d-vmuyzemnik-a-yu-ooo-npp-geotekannotaciya.html

13. Manual for LS-DYNA Soil Material Model 147 Evaluation / Report No FHWA-HRT-04095. Lincoln, University of Nebraska, 77 pages.

14. Huang Y., Willford M.R. Validation of LS-DYNA ${ }^{\circledR}$ MMALE with Blast Experiments // 12th International LS-DYNA® Users Conference. 2012. URL: https://www.dynalook.com/12thinternational-ls-dyna-conference/blastimpact20-c.pdf

15. Goel M., Matsagar V., Gupta A. An Abridged Review of Blast Wave Parameters. // Defense Science Journal, 2012, Volume 62, Issue 5, pp. 300-306.

16. Бате К., Вилсон Е. Численные методы анализа и метод конечных элементов. М.: Стройиздат. 1982. - 448 с.

17. Van Leer B.J. Towards the ultimate conservative difference scheme. Second-order sequel to Godunov's Method. // Journal of Computational Physics, 1979, Volume 32, Issue 1, pp. 101-136.

18. LS-DYNA. Keyword user's manual. 2017. Volume I. Version 971. Livermore Software Technology Corporation (LSTC). URL: https://www.dynasupport.com/manuals/lsdyna-manuals/ls-dyna-manual-r-8.0-vol-iii

19. Андреев С.Г., Бабкин А.В., Баум Ф.А., Имховик Н.А., Кобылкин И.Ф., Колпаков В.И., и др. Физика взрыва. В 2 томах. - М.: ФИЗМАТЛИТ, 2004. - 832 c.

Oleg V. Mkrtychev, Professor, Dr.Sc., Department of Strength of Materials, National Research Moscow State University of Civil Engineering; 26, Yaroslavskoe Shosse, Moscow, 129337, Russia;

phone: +7(499)183-85-59;

E-mail: mkrtychev@yandex.ru.

Anton Y. Savenkov, Ph.D. student, Department of Strength of Materials, National Research Moscow State 
University of Civil Engineering; 26, Yaroslavskoe Shosse, Moscow, 129337, Russia;

phone: +7(499)183-85-59;

E-mail: savenkov.asp@mail.ru.

Мкрытчев Олег Вартанович, профессор, доктор технических наук; профессор кафедры сопротивления материалов, Национальный исследовательский Московский государственный строительный университет; 129337, Россия, г. Москва, Ярославское шоссе, дом 26; тел. +7(499)183-85-59;

E-mail: savenkov.asp@mail.ru.

Савенков Антон Юрьевич, аспирант кафедры сопротивления материалов, Национальный исследовательский Московский государственный строительный университет; 129337, Россия, г. Москва, Ярославское шоссе, дом 26; тел. +7(499)183-85-59;

E-mail: savenkov.asp@mail.ru. 